\title{
Dynamics of phytoplankton diversity structure and primary productivity in the English Channel
}

\author{
Camille Napoléon ${ }^{1,2,3}$, Liliane Fiant ${ }^{3}$, Virginie Raimbault ${ }^{1,2}$, Philippe Riou ${ }^{3}$, \\ Pascal Claquin ${ }^{1,2, *}$
}

\author{
${ }^{1}$ Université de Caen Basse-Normandie, UMR BOREA, 14032 Caen, France \\ ${ }^{2}$ UMR BOREA, CNRS-7208, IRD-207, MNHN, UPMC, UCBN, 14032 Caen, France
}

${ }^{3}$ IFREMER, Laboratoire Environnement Ressources de Normandie, Avenue du Général de Gaulle, 14520 Port-en-Bessin, France

\begin{abstract}
The dynamics of the phytoplankton assemblage, the physical, chemical and biological parameters, and primary productivity and production were monitored in the central English Channel along a transect between Ouistreham and Portsmouth from January to December 2010. The spatial patterns of the phytoplankton assemblage were controlled by the hydrological characteristics of the water masses, and the annual structure of the phytoplankton assemblage was characteristic of the central English Channel and was controlled by seasonality. The spring bloom was dominated by a single species, Chaetoceros socialis, and associated with low microphytoplankton evenness and Shannon-Wiener indices, whereas the evenness index was high from late spring to winter and associated with the proliferation of pico- and nanophytoplankton cells. We identified 2 species responsible for harmful algal blooms, Phaeocystis globosa, which dominated the community in the northern part of the Seine Bay in May, and Lepidodinium chlorophorum, which dominated the community near the French coast in September. We examined the relationship between microphytoplankton diversity and maximum primary production and productivity. We found a negative parabolic relationship between the diversity indices (evenness and Shannon-Wiener) and maximum primary production, and a positive parabolic relationship between the number of taxa (richness) and maximum primary production. However, we found no relationship between maximum productivity and the evenness or richness indices. High levels of productivity were measured during the increasing abundance of pico and nanophytoplankton cells, highlighting the importance of taking the dominant functional group into account, rather than the degree of diversity, when explaining the level of productivity.
\end{abstract}

KEY WORDS: Phytoplankton diversity · Primary production · Productivity $\cdot$ English Channel

Resale or republication not permitted without written consent of the publisher

\section{INTRODUCTION}

In marine systems, primary production is largely driven by physical and chemical parameters (Falkowski \& Raven 2007, Napoléon et al. 2012). Many studies have focused on the relationship between primary production and nutrients (Lippemeier et al. 1999, Behrenfeld et al. 2004, Claquin et al. 2010) or temperature (Davison 1991, Claquin et al. 2008), while others have focused on the relationship between primary production and incident light (Anning et al. 2000). Biological parameters such as the structure of the phytoplankton assemblage can majorly influence the variability in primary production and productivity (Behrenfeld \& Falkowski 1997, Videau et al. 1998, Jouenne et al. 2005, 2007, Duarte et al. 2006, Claquin et al. 2010). The dynamics in the phytoplankton assemblage are mainly controlled by seasonal changes in light and nutrient concentrations (Huisman \& Weissing 1995), but physical and chemical parameters can also influence the relative abundances of picophytoplankton and microphytoplank- 
ton cells. For example, high temperatures and oligotrophic waters stimulate the development of picophytoplankton (Agawin et al. 2000), while microphytoplankton tend to dominate coastal and eutrophic waters (Pannard et al. 2008).

It is well known that the structure and diversity of the phytoplankton assemblage drive productivity and hence carbon input into marine systems (Mittelbach et al. 2001, Gamfeldt \& Hillebrand 2011). Some studies have focused on the relationship between productivity and the biodiversity of ecosystems, but the shape of the relationship is variously reported as a negative linear relationship, a positive linear relationship, a unimodal relationship, or no relationship at all (Abrams 1995, Waide et al. 1999, Jouenne et al. 2007, Chase 2010, Claquin et al. 2010).

Limited species diversity can reduce productivity and this can explain the positive linear diversityproductivity relationship, which is the one most frequently found. Mechanisms that might explain this relationship include: (1) an increasing level of diversity increases the probability that a highly productive species could be present in a phytoplankton assemblage, and (2) the complementarity of species could lead to higher productivity in systems characterized by high diversity (Tilman et al. 1997, Loreau 1998). The unimodal diversity-productivity relationship can be explained by competitive exclusion occurring as productivitiy increases and resource availability decreases (Huston \& Deangelis 1994, Duarte et al. 2006). The negative linear relationship is observed when high production is associated with low biodiversity due to the domination by one or few species which exclude other taxa from the ecosystem. The different diversity-productivity relationships described in the literature indicate that the level of diversity that triggers productivity is still not clear. The complexity of (and variability in) environmental factors may explain the heterogeneity of the diversity-productivity relationship, as may the different methodologies used to describe the degree of diversity.

In this context and in order to improve our understanding of the diversity-productivity relationship, the dynamics in, and diversity of, phytoplankton assemblages need to be further monitored and described in parallel with environmental (physical and chemical) parameters. The English Channel (northwestern Europe) is an epicontinental sea under strong anthropogenic pressure. Napoléon et al. (2012) describe 4 distinct hydrological areas along a transect that transverses the central region of the English Channel. The functioning of each hydrologi- cal area depends mainly on nutrient inputs from rivers and on offshore influences (Napoléon et al. 2012). It is consequently useful to study the dynamics of the community structure, diversity and primary production in this highly variable system.

In the present study we monitored the dynamics of the phytoplankton assemblage, the physical, chemical, and biological parameters, and primary productivity and production, in the central English Channel, along a transect between Ouistreham and Portsmouth, over a period of $1 \mathrm{yr}$. Our objectives were to (1) study the influence of the physical, chemical, and biological parameters on the dynamics in the phytoplankton assemblage, (2) monitor the spatiotemporal variability in the microphytoplankton diversity at 2 scales (intra-station and inter-station) and identify common patterns between seasons, and (3) identify possible relationships between phytoplankton biomass, phytoplankton dynamics, and primary production.

\section{MATERIALS AND METHODS}

\section{Sampling strategy}

Monthly measurements were made from January to December 2010 in the central region of the English Channel (except in April and November). Data were collected in daylight on board the Normandie-Brittany ferries during their daily $175 \mathrm{~km}$ crossing between Ouistreham (France, 49 $17^{\prime} 27^{\prime \prime} \mathrm{N}, 000^{\circ} 14^{\prime}$ $45^{\prime \prime} \mathrm{W}$ ) and Portsmouth (Great Britain, 50 48' 49" N, $001^{\circ} 05^{\prime} 29 \mathrm{~W}$ ) (Fig. 1). Physical parameters (temperature, salinity and incident light) were recorded every $500 \mathrm{~m}$, photosynthetic parameters were measured every $5 \mathrm{~km}$ and biological (chl a, phytoplankton spe-

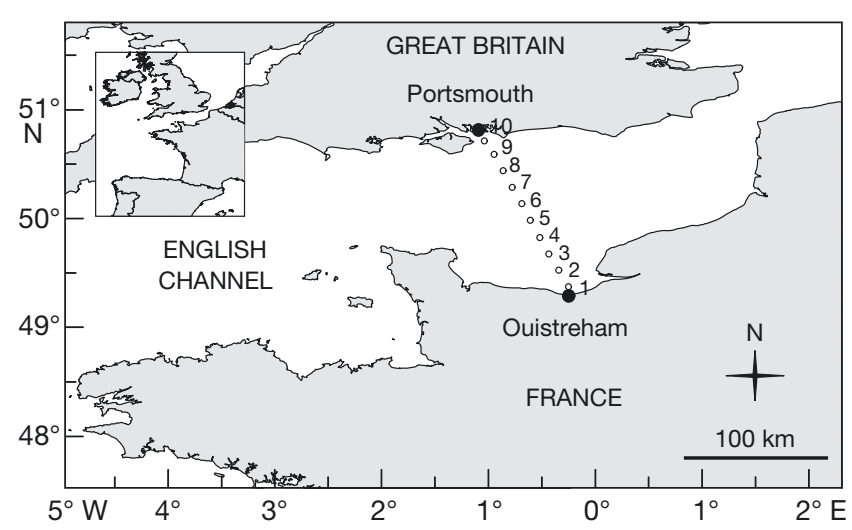

Fig. 1. The English Channel, with the location of the sampling transect and the 10 stations at which complete data sets were obtained 
cies, suspended particular matter) and chemical parameters (dissolved inorganic nitrogen, phosphate and silicate) every $15 \mathrm{~km}$. The data set is thus complete for 10 sampling stations (Fig. 1). Water samples were collected by using the difference in pressure between the seawater (1.4 bar) and the ship (1 bar) through a pipe let down from the front of the ship to a depth of $4 \mathrm{~m}$. Sampling stopped in the vicinity of the harbour to limit possible contamination by polluted waters. Supplementary data, including time and position (latitude, longitude) were provided by the crew.

\section{Chl $a$, physical, and chemical parameters}

The chl a concentration was measured using the method of Welschmeyer (1994; see also the description in Napoléon et al. 2012). Temperature and salinity were recorded with a YSI 6600 V2 multi-parameter probe, and light was measured on deck with a $2 \pi$ PAR sensor LI-192 connected to a LI-1400 data logger (LI-COR). Dissolved inorganic nitrogen (DIN), phosphate (DIP) and silicate (DSi) concentrations were determined in the laboratory using an AxFlow AA3 autoanalyzer, following the method of Aminot \& Kérouel (2007). Concentrations of suspended particulate matter (SPM) were measured using the method of Aminot \& Chaussepied (1983).

\section{Species composition}

Microphytoplankton. Immediately after sampling, $1 \mathrm{l}$ of water was preserved using acid Lugol's solution $\left(2 \mathrm{ml} \mathrm{l}^{-1}\right)$. The Utermöhl (1931) method was used for the analysis of the composition and concentration of microphytoplankton. After homogenisation, a $10 \mathrm{ml}$ water sample was poured into a sedimentation chamber and left to settle for at least $8 \mathrm{~h}$. The phytoplankton cells on the chamber bottom were identified and counted using an inverted microscope. Organisms were identified to the lowest taxonomic level possible, depending on the skill of the operator (a single operator was involved for all taxonomic analysis). The strategy used for each species was to count the whole bottom of the chamber, half the bottom, or along a diagonal, depending on the abundance of the species. The same magnification $(400 x)$ was used in all cases and the counts are expressed in cells $\mathrm{l}^{-1}$.

Pico- and nanophytoplankton. Analyses of picoand nanophytoplankton samples and processing of flow cytometric data (FACSCanto II flow cytometer,
BD-Biosciences) were performed at the Laboratoire National d'Analyse en Cytométrie en Flux, CNRS INSU, Observatoire Océanologique de Banyuls sur mer, France. The samples were fixed with glutaraldehyde at a final concentration of $1 \%$, frozen in liquid nitrogen, stored at $-80^{\circ} \mathrm{C}$, and were then thawed at room temperature immediately before cytometric analysis (Vaulot et al. 1989). A blue argon laser (excitation at $488 \mathrm{~nm}$ ) was used to distinguish and count autotrophic and heterotrophic cells. Phototrophic cells were enumerated according to their right-angle light scatter properties (SSC, roughly related to cell size), and the orange (585/42 $\mathrm{mm} \mathrm{BP}$ ) and red (670 $\mathrm{nm} \mathrm{LP})$ fluorescence from phycoerythrin and chlorophyll pigments, respectively. Data were acquired using FACSDiva software (BDBiosciences). Fluorescent $1.002 \mu \mathrm{m}$ beads (Polysciences) were systematically added to each analysed sample to normalize cell fluorescence and light scatter emission, thus making it possible to compare the results. To estimate cell abundances accurately, the flow rate of the sample was routinely measured every 10 samples using BD Trucount tubes (Cat. 340334; Lot 822525).

\section{Productivity and primary production}

We used the maximum primary production $\left(\mathrm{PP}_{\max }\right.$ that we transformed from $\mathrm{mg} \mathrm{C} \mathrm{l}^{-1} \mathrm{~h}^{-1}$ to $\mathrm{mg} \mathrm{C} \mathrm{m} \mathrm{C}^{-2}$ $\mathrm{d}^{-1}$ ) data of Napoléon \& Claquin (2012) and calculated maximum productivity rates $\left(\mathrm{P}^{\mathrm{B}}{ }_{\max }\right)$ using:

$$
\mathrm{P}_{\text {max }}^{\mathrm{B}}=\mathrm{PP}_{\max } /[\mathrm{chl} a]
$$

where $\mathrm{P}_{\text {max }}^{\mathrm{B}}$ is expressed in $\mathrm{mg} \mathrm{C} \mathrm{mg}^{-1} \mathrm{chl} \mathrm{a} \mathrm{h}^{-1}, \mathrm{PP}_{\max }$

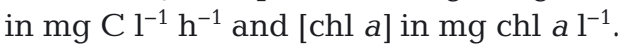

\section{Diversity indices}

To characterise the species richness of the microphytoplankton community, we counted the number of taxa $(S)$ in each sample. The Shannon-Wiener index $\left(H^{\prime}\right)$ of the microphytoplankton was calculated using:

$$
H^{\prime}=-\mathrm{S}_{i=1}{ }^{S} p_{i} \ln \left(p_{i}\right)
$$

and the evenness index $\left(J^{\prime}\right)$ was calculated following the widely used formula of Pielou (1966):

$$
J^{\prime}=\left[\mathrm{S}_{i=1}{ }^{S} p_{i} \ln \left(p_{i}\right)\right] / \ln (S)
$$

where $p_{i}$ is the proportion of the microphytoplankton species $i$. 


\section{Statistical analyses}

Canonical correspondence analysis (CCA) was performed using R v.2.11.1, to examine the relationship between physical, chemical, and biological parameters and the structure of the phytoplankton assemblage. For this analysis, a matrix was built containing the physical and chemical parameters, the biological parameters, and the abundance of each microphytoplankton species in the samples. Microphytoplankton species abundance data (cells $\mathrm{I}^{-1}$ ) were $\log$-transformed $\left[\log _{10}(x+1)\right]$ as this variable may have an asymmetric distribution due to exponential growth when conditions are favourable (Ter Braak \& S̆milauer 2002). Physical, chemical, and biological data were centered by the mean of the variable and reduced by the variance. CCA is an efficient ordination technique when a Gaussian relationship between species and the environmental gradients is expected (Ter Braak 1986). This constrained analysis extracts the best environmental gradients that explain the maximum variability in species data. Biological variables (chl $a$, diatom, dinoflagellate, Synechococcus and picoeukaryote concentrations, $\mathrm{PP}_{\max }, \mathrm{P}_{\text {max }}^{\mathrm{B}}$ species richness $S$, Shannon-Wiener index $H^{\prime}$, and the microphytoplankton evenness index $J^{\prime}$ ) were added as supplementary variables to the CCA, and were thus correlated with the canonical axis (which is a linear combination of environmental parameters) on the plot (Klein et al. 2011).

To resolve the space and time variability in the structure of the microphytoplankton community, partial triadic analysis (PTA) was applied to the data set using the ADE-4 package (Chessel et al. 2004, Dray \& Dufour 2007) with the R v.2.11.1 software. The data were organised in sub-matrices. A sub-matrix containing the composition of microphytoplankton species recorded for all sampling dates was built for each station. The data (cells $\mathrm{l}^{-1}$ ) were log-transformed $[\log 10(x+1)]$ to obtain a normal distribution. The PTA analysis compares the structures shared by the submatrices and identifies stations with a similar temporal structure. Ward's cluster analysis based on the vector correlation coefficients of the PTA was performed to distinguish groups of stations according to their microphytoplankton composition (Ward 1963).

To study the relationship between microphytoplankton richness and $\mathrm{PP}_{\max }$ as well as between the microphytoplankton evenness index and $\mathrm{PP}_{\max }$ quadratic polynomial regression analyses were carried out on the data set using SigmaPlot v.11.0 (Systat Software).
To identify inter-site and intra-site variability, we used the double principal coordinate analysis (DPCoA) developed by Pavoine et al. (2004). This analysis makes it possible to break down total inertia into the inertia of species around stations (intra-station diversity) and the inertia between stations (inter-station diversity). The intra-station diversity is the inertia (variance) of species weighted by their relative abundance at the station concerned, within the space of the DPCoA. Conversely, the inter-station variability is the inertia of all the stations weighted by the weight vector of each station within the space of the DPCoA. DPCoA were performed with R v.2.11.1 using the ADE-4 package (Pavoine et al. 2004). A single matrix was built containing the frequencies of microphytoplankton species at each station and at each sampling date, with species listed in the columns and the station/date in the rows.

\section{RESULTS}

\section{Spatiotemporal variability in biological parameters}

The phytoplankton biomass (chl $a$, data from Napoléon et al. 2012) and the number of diatom cells showed the same pattern, but the pattern varied considerably over time and in space (Fig. 2A,B). The highest values were observed from the French coast to the northern part of the Seine Bay, between the end of winter and June. The highest chl a concentration $\left(7.2 \mu \mathrm{g} \mathrm{l}^{-1}\right)$ was observed in March and the highest number of diatom cells ( 955800 cells l$^{-1}$ ) was observed in May. A weaker winter/spring proliferation was observed near the English coast (i.e. Stns 9 and 10) from January to May, with a maximum chl a concentration of $3.3 \mathrm{\mu g} \mathrm{l}^{-1}$ and a maximum number of

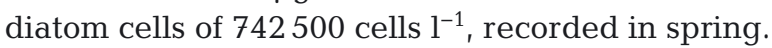

Compared to the concentrations of diatoms, concentrations of dinoflagellates remained low throughout the year of our study (Fig. 2C). Dinoflagellates proliferated later than diatoms, i.e. between July and September, with values ranging between 2400 and

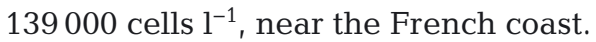

The highest concentrations of cryptophytes were recorded between May and July on both coasts, the highest value being 1642 cells ml $^{-1}$ recorded in May near the French coast (Fig. 2D).

The concentrations of picoeukaryotes (Fig. 2E) and Synechococcus (Fig. 2F) showed the same spatiotemporal pattern over the year $\left(\mathrm{r}_{\text {Picovsyne }}=0.802\right)$. The highest values were recorded between the English coast and the centre of the English Channel, espe- 

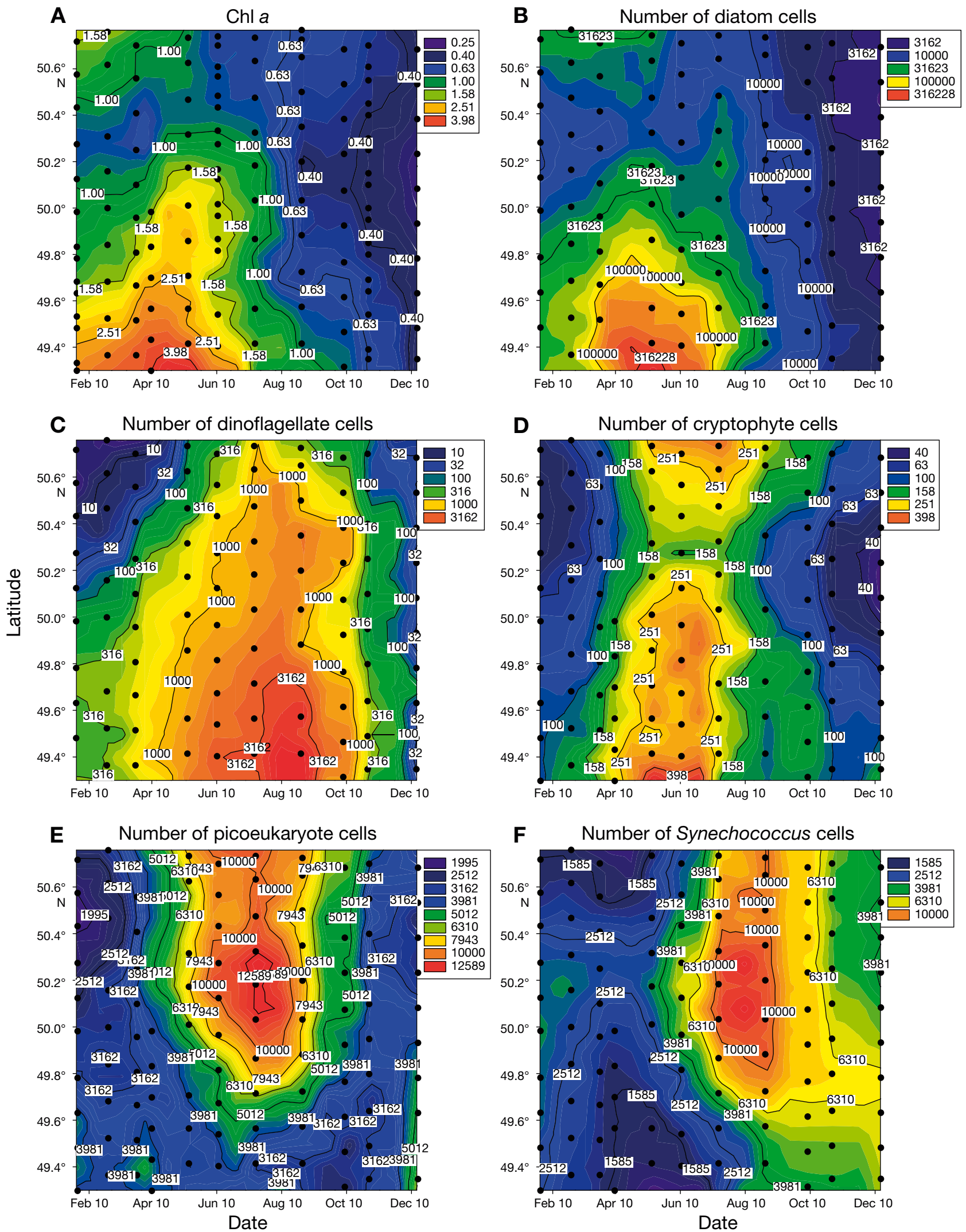

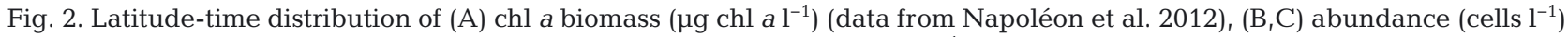
of (B) diatoms and (C) dinoflagellates, and (D-F) abundance (cells ml-1) of (D) cryptophytes, (E) picoeukaryotes, and (F) Synechococcus spp. 
cially in the centre of the English Channel between June and August. The overall highest values, 32835 cells ml ${ }^{-1}$ for picoeukaryotes and 55067 cells ml ${ }^{-1}$ for Synechococcus, were recorded in July at latitude $50.0^{\circ} \mathrm{N}$.

Microphytoplankton $S$ (Fig. 3A) varied over time and in space. A decreasing south-north gradient was observed along the transect, with the highest number of taxa (33 taxa sample ${ }^{-1}$ ) observed in May at latitude $49.4^{\circ} \mathrm{N}$. Microphytoplankton $H^{\prime}$ (Fig. 3B) and $J^{\prime}$ (Fig. 3C) showed the same spatiotemporal variability over the year except in November-December where $H^{\prime}$ dropped and $J^{\prime}$ remained high. Minimum values were recorded between the end of winter and the end of spring from the French coast to the centre of the English Channel. The lowest $H^{\prime}(0.25)$ and the lowest $J^{\prime}(0.09)$ were recorded in May at latitude $49.9^{\circ} \mathrm{N}$.

$\mathrm{PP}_{\max }$ showed the same spatiotemporal pattern as microphytoplankton $S$ except for the relatively high values recorded on the English coast over the year (Fig. 3D). The highest $\mathrm{PP}_{\max }$ value, $28.7 \mathrm{mg} \mathrm{C} \mathrm{m}^{-2} \mathrm{~d}^{-1}$, was measured in June in the centre of the English Channel.

$\mathrm{P}^{\mathrm{B}}$ max (Fig. 3E) remained low near the French coast throughout the year of study. High values were recorded between May and December between the English coast and latitude $49.8^{\circ} \mathrm{N}$ with a maximum value of $10.6 \mathrm{mg} \mathrm{C} \mathrm{mg}^{-1} \mathrm{chl} \mathrm{a} \mathrm{h} \mathrm{h}^{-1}$ recorded in July at latitude $50.0^{\circ} \mathrm{N}$.

\section{Phytoplankton assemblage dynamics}

We used CCA to link the variability in the structure of phytoplankton assemblage to physical, chemical, and biological parameters (Fig. 4). The first 2 axes of the CCA explained more than $59 \%$ of the variance of the data set (Axis 1: $37.74 \%$; Axis 2: $21.60 \%$ ). Monte Carlo permutation tests showed that all the canonical axes $(p<0.001)$ were statistically significant. As previously reported in Napoléon et al. (2012), physical, chemical, and biological parameters revealed temporal uncoupling due to the seasonality of the parameters (Fig. 4A). The high concentrations of diatom cells were positively linked to high concentrations of chl $a$, $\mathrm{PP}_{\max }, S$, and irradiance, and negatively linked to $J^{\prime}$, $H^{\prime}$, and concentrations of DSi. Conversely, dinoflagellate concentrations were linked to high $\mathrm{P}^{\mathrm{B}}{ }_{\max }$ and high temperatures, and low DIN and chl a concentrations. Synechococcus concentrations were positively linked to $\mathrm{P}_{\text {max }}^{\mathrm{B}}$ and negatively linked to high nutrient concentrations, and positively to picoeukaryote con- centrations, which, in turn, were positively linked to $\mathrm{PP}_{\max }$.

A clear seasonal structure was apparent in the phytoplankton assemblage throughout the year of study (Fig. 4B). On the left part of the CCA (Fig. 4B,C), the summer and autumn communities were characterised by dinoflagellates, while diatoms were observed throughout the year (Fig. 4B,C) with the highest concentrations in spring (Fig. 4A,B). The spring diatom peak near the French coast was mainly dominated by diatoms of the genus Chaetoceros, particularly C. socialis (C_s) in May (880900 and 846000 cells $\mathrm{l}^{-1}$ at Stns 1 and 2, respectively). In contrast, the community near the English coast was characterised by Skeletonema spp., (Sk) (449000 cells $1^{-1}$ ) and 3 species of Thalassiosira (T. levanderi [T_l], T. minima [T_m] and T. nordenskioeldii [T_no], total of 294500 cells $\mathrm{l}^{-1}$ ), with the highest concentrations recorded in March at Stn 10. The summer/autumn peak of dinoflagellates was characterised by Lepidodinium chlorophorum (L_C) (Fig. 4C), with a maximum concen-

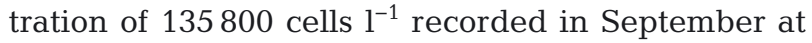
Stn 2. A high concentration of Phaeocystis globosa (P_g) (444 400 cells l $^{-1}$ ) was recorded in May at Stn 4.

\section{Spatial variability}

The PTA interstructure analysis enabled us to detect similarities in the structure of the community of microphytoplankton between stations over the year of study. The first eigenvalue of the PTA analysis represents more than $31 \%$ of the total inertia and is isolated from the others (Fig. 5A). This suggests a close link between stations, which in turn indicates a strong common temporal structure of the microphytoplankton assemblage between stations. The second eigenvalue represents more than $11 \%$ of total inertia (Fig. 5A) and highlights the differences between stations (Fig. 5B). Based on Ward's cluster analysis (Fig. 5C), the transect between Ouistreham and Portsmouth can be divided into 3 groups of stations: Stns 1 to $3_{i}$, Stns 4 to 8, and Stns 9 and 10.

\section{Diversity}

A significant quadratic polynomial relationship was found between microphytoplankton $S$ and $\mathrm{PP}_{\max }$ (Fig. 6A), between microphytoplankton $J^{\prime}$ and $\mathrm{PP}_{\max }$ (Fig. 6B) and between $H^{\prime}$ and $\mathrm{PP}_{\max }$ (data not shown, $\left.\mathrm{R}^{2}=0.066, y=-0.0010 x^{2}+0.0088 x+1.7590\right)$. There was thus a positive link between $S$ and $\mathrm{PP}_{\max }(\mathrm{p}<$ 

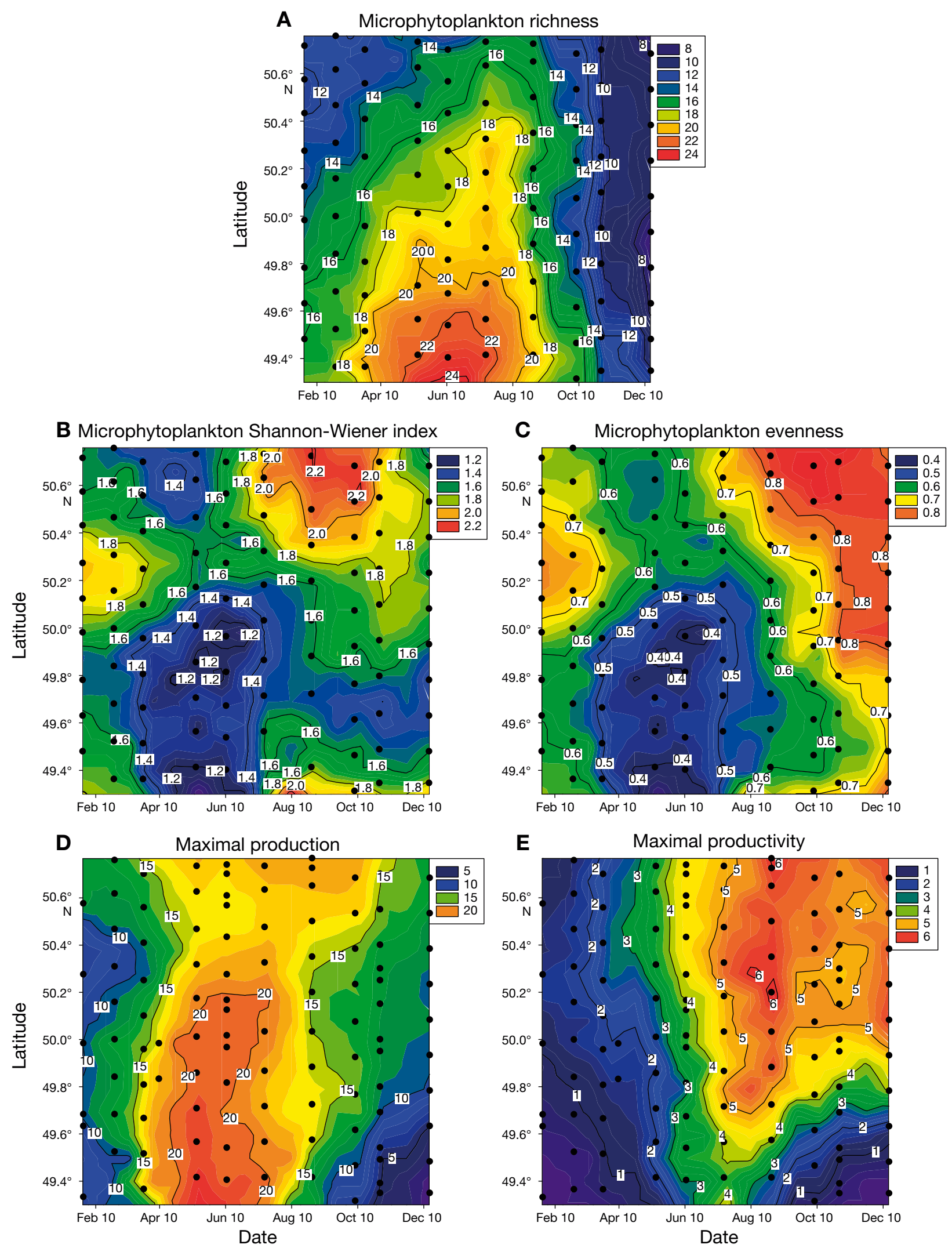

Fig. 3. Latitude-time distribution of (A) microphytoplankton richness $S$ (taxa sample ${ }^{-1}$ ), (B) microphytoplankton ShannonWiener index $\left(H^{\prime}\right),(\mathrm{C})$ microphytoplankton evenness index (Pielou's $\left.J^{\prime}\right)$, (D) maximal production, $\mathrm{PP}_{\max }\left(\mathrm{mg} \mathrm{C} \mathrm{m}^{-2} \mathrm{~d}^{-1}\right)$, and (E) maximal productivity, $\mathrm{P}_{\text {max }}^{\mathrm{B}}\left(\mathrm{mg} \mathrm{C} \mathrm{mg}^{-1} \mathrm{chl} \mathrm{a} \mathrm{h}^{-1}\right)$ 


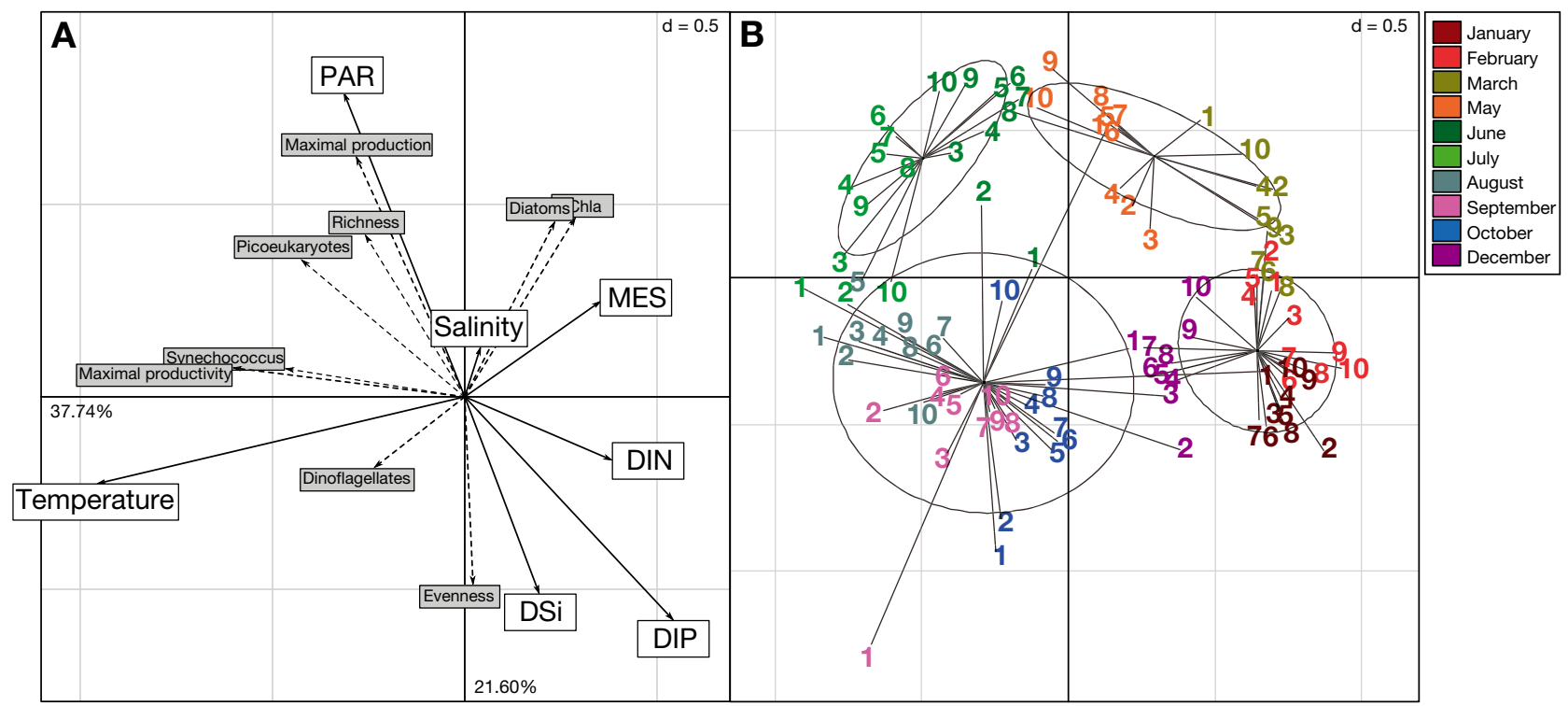

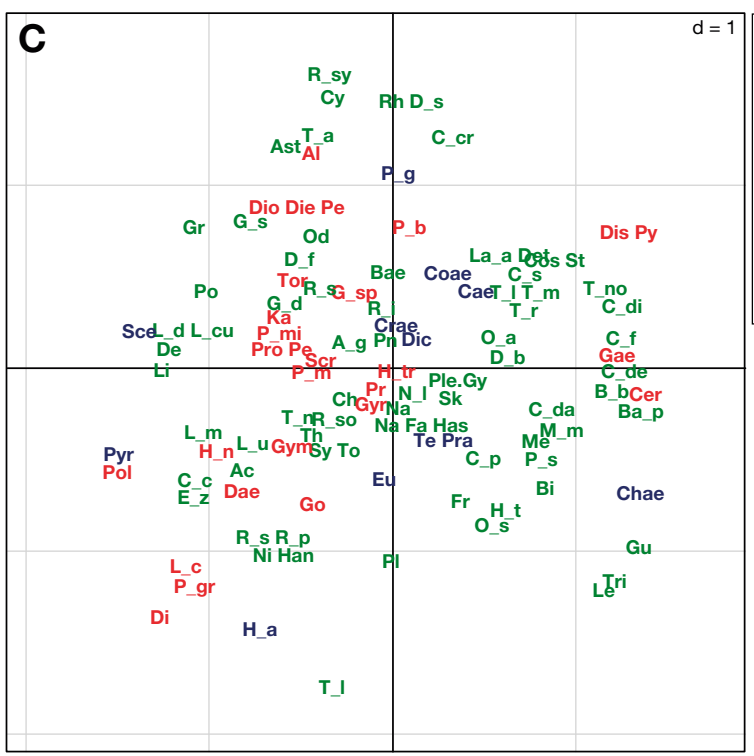

0.0001 ), and a negative link between $J^{\prime}$ and $\mathrm{PP}_{\max }$ $(\mathrm{p}<0.0001)$ and between $H^{\prime}$ and $\mathrm{PP}_{\max }(\mathrm{p}<0.05)$. However, the low values of $\mathrm{R}^{2}$ (Fig 6A,B) show that part of the variability in $S$ and $J^{\prime}$ are not explained by $\mathrm{PP}_{\max }$ and vice-versa.

We used double principal coordinate analysis (DPCoA) (Pavoine et al. 2004) to break microphytoplankton diversity down to 2 levels (inter-station and intra-station) in only one space. In Fig. 7, the projection of the stations on the 2 first axes highlights the variability among stations, while the size of the square shows the level of intra-station diversity given by the inertia in the species around each station.

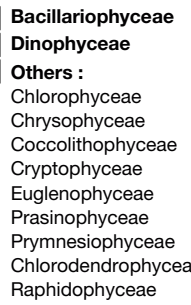

Fig. 4. Canonical correspondence analyses. (A) Relation between physical, chemical, and biological parameters and species. White indicates active variables and grey indicates supplementary variables. (B) Projection of samples (colours refer to the date and the number of the station) and (C) projection of species (see species list in the Appendix)

High intra-station and inter-station microphytoplankton diversity was observed in January (Fig. 7A) and February (Fig. 7B), as well as in October (Fig. 7I) and December (Fig. 7J), i.e. in winter and autumn.

The proliferation of diatoms in May (Fig. 7D) was characterised by low diversity. The structure of the community at Stn 3 and at Stns 5 to 10 was nearly identical, as it was at Stns 1 and 2. Moreover, low intra-station diversity was observed at Stns 1,2 and 4, due to the proliferation of $C$. socialis at Stns 1 and 2 and of P. globosa at Stn 4. The beginning (Fig. 7C) and end (Fig. 7E) of the diatom proliferation were characterised by high inter-station diversity compared with 


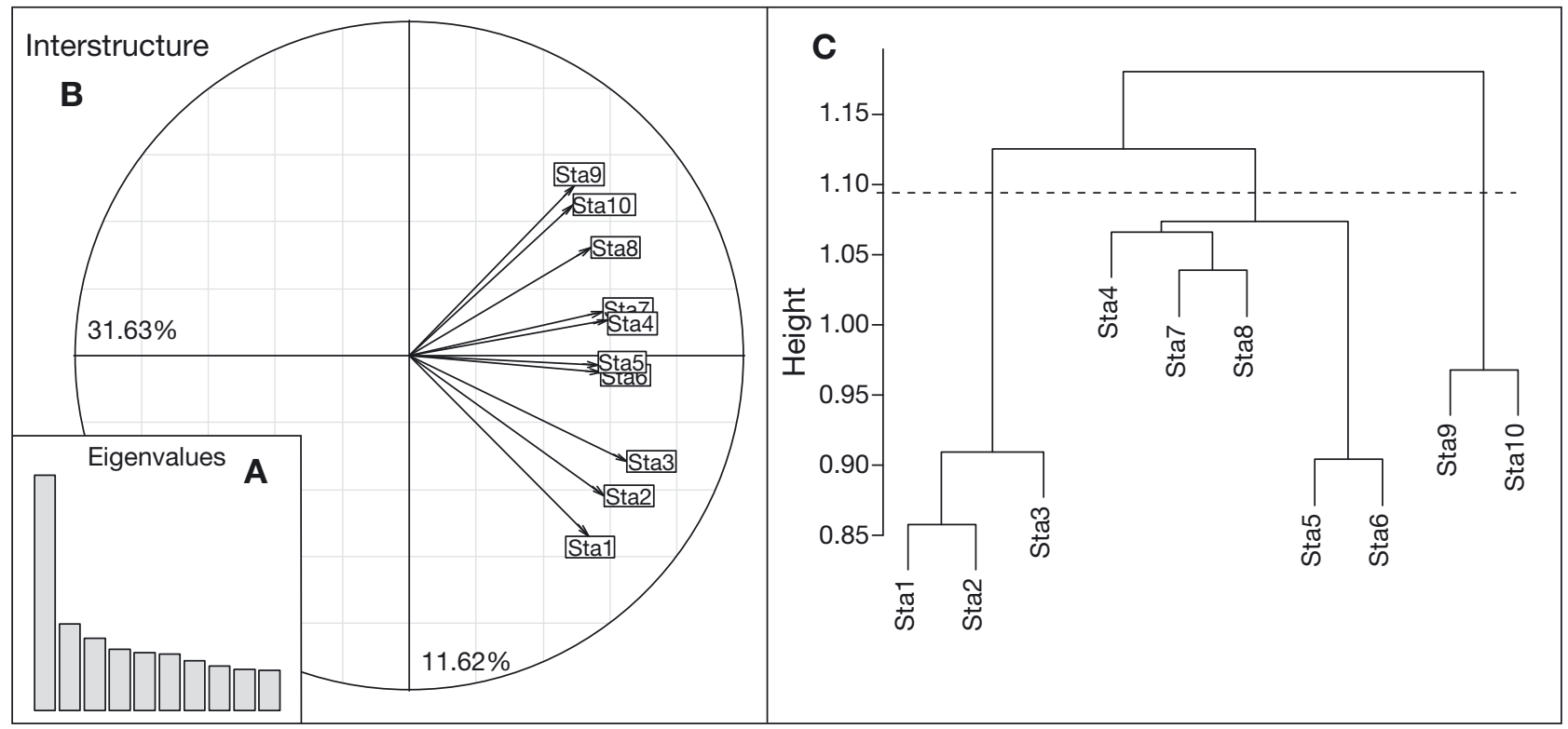

Fig. 5. Partial triadic analysis (PTA) interstructure analysis. (A) Histogram of eigenvalues based on the diagonalization of the RV matrix, (B) ordination of the stations given by the 2 first eigenvectors of the vector correlation matrix, and (C) tree topology obtained with Ward's cluster analysis

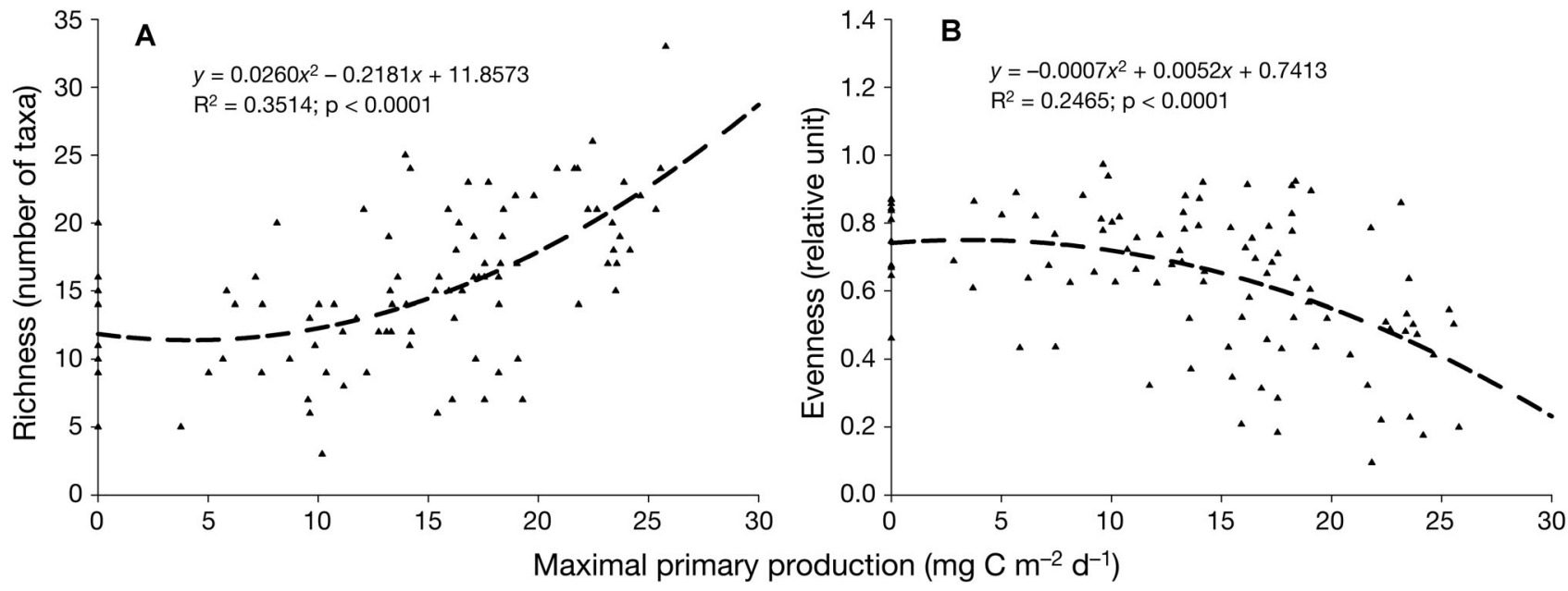

Fig. 6. (A) Species richness $\left(S\right.$; number of taxa) and (B) evenness $\left(J^{\prime}\right)$ as a function of maximum primary production. Dotted lines represent the polynomial regression of the relationship

May. During those periods, Stns 1 to 3 and Stns 9 and 10 showed the same microphytoplankton community structure. Community structure at Stns 4 to 7 resembled that of the coastal stations in March but Stns 4 to 7 had their own community structure in June.

In July (Fig. 7F), August (Fig. 7G) and September (Fig. $7 \mathrm{H}$ ), when the highest concentrations of dinoflagellates were observed, Stns 1, 8, 9 and 10 showed the same microphytoplankton community structure. From July to September, the dynamics at Stn 3, located in the north of the Seine Bay, differed from the dynamics at Stns 1, 8, 9 and 10. Other stations were either associated with Stns 1, 8, 9 and 10 or were characterised by the proliferation of 1 taxon. For example, Chlorophyceae were prolific in July at Stn 4 (82\% of the total number of microphytoplankton cells), Leptocylindrus danicus and L. curvatulus were prolific in August at Stn 7 (79\% of the total number of microphytoplankton cells) and Lepidodinium chlorophorum were prolific in September at Stn 2 (90\% of the total number of microphytoplankton cells). 


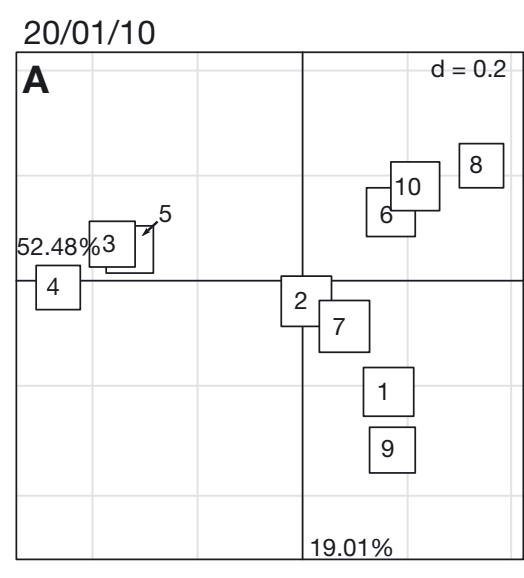

$18 / 02 / 10$

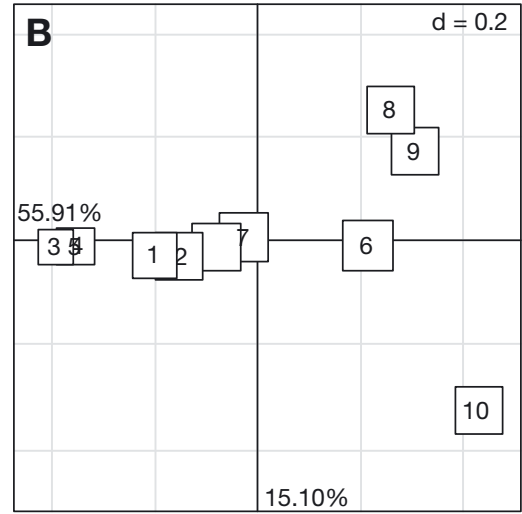

\section{$02 / 06 / 10$}

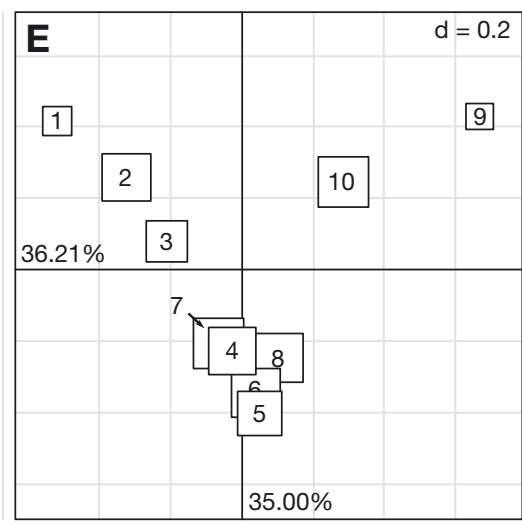

\section{$29 / 09 / 10$}

20/08/10

G

$d=0.2$

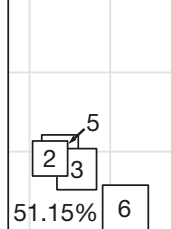

7

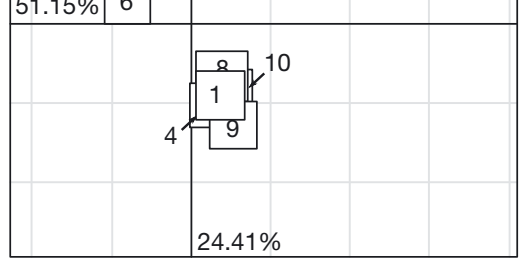

$07 / 12 / 10$

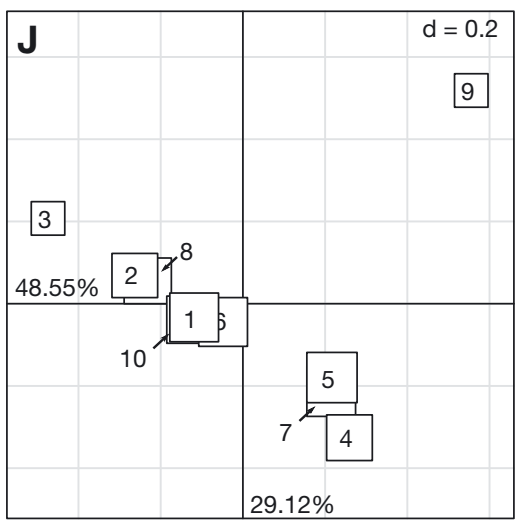
$0.1 \square \quad 0.3 \square \quad 0.5 \square$
0.7
0.9

$17 / 03 / 10$

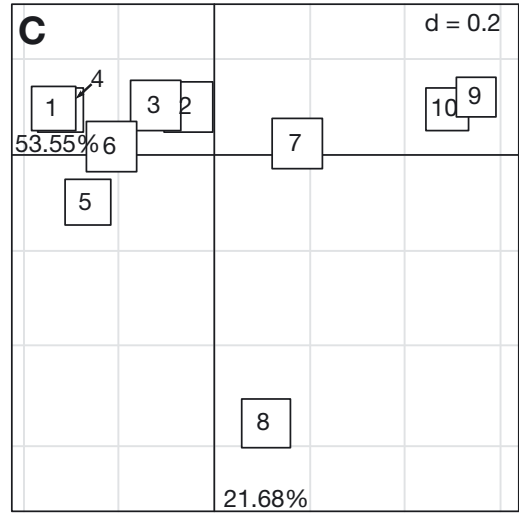

07/07/10

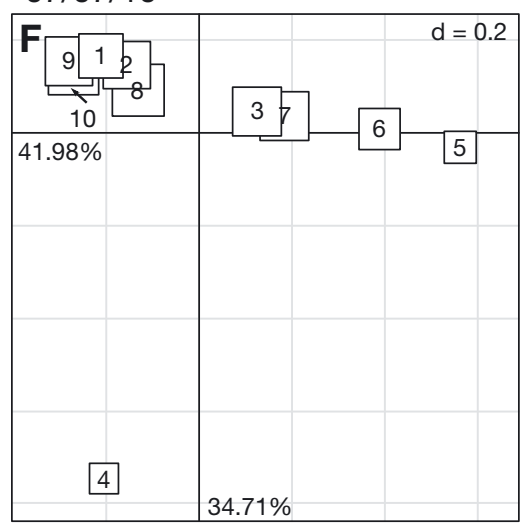

$22 / 10 / 10$

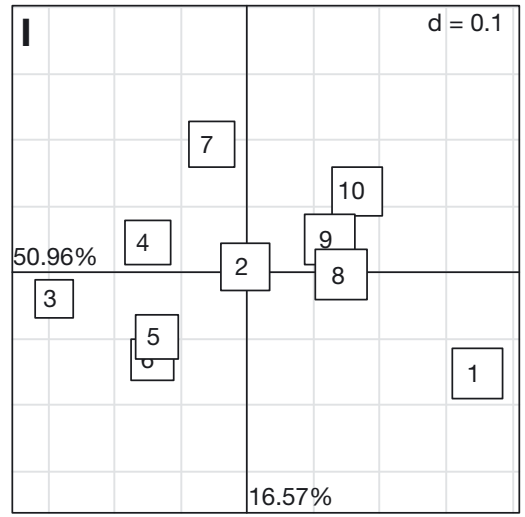

Fig. 7. Double principal coordinate analyses (DPCoA) in the plane defined by the 2 first axes of the analyses. Variability in stations (inter-station diversity) and inertia of species around each station (intra-station diversity) for 10 sampling dates in 2010 (dates given above each panel). Inter-station diversity is represented by the distance between stations (the longer the distance, the greater the diversity) and intra-station diversity is represented by the size of the square (the larger the square, the greater the diversity) 


\section{DISCUSSION}

\section{Phytoplankton assemblage dynamics}

The structure of the phytoplankton assemblage was characterised by spatial variability. The differences between stations were the magnitude and the composition of the phytoplankton assemblage. Napoléon et al. (2012) showed that the transect between Ouistreham and Portsmouth can be divided into 4 distinct hydrological areas: (1) the French coastal area, which receives large freshwater inputs, (2) the area north of the Seine Bay, which is influenced by nutrient inputs from the River Seine and offshore inputs (Menesguen \& Hoch 1997, Cugier et al. 2005), (3) the centre of the English Channel (CentreEC), and (4) the English coastal area (UKcoast), which has low nutrient concentrations despite its proximity to the coast. In the present study, the PTA interstructure analysis performed on microphytoplankton species data identified almost the same areas as those found by Napoléon et al. (2012). This result confirms the role of hydrodynamic characteristics in the geographical structure of phytoplankton assemblage, as reported in other studies (Jones et al. 1984, Estrada et al. 1999, Gailhard et al. 2003).

The general annual pattern of the phytoplankton assemblage found in the present study is characteristic of the central English Channel and is controlled by seasonality (Videau et al. 1998, Gailhard 2003, Domingues et al. 2005, Jouenne et al. 2007, Pannard et al. 2008). This pattern is characterised by 4 periods: (1) low biomass in winter, (2) an extensive spring bloom from March to May dominated by diatoms and especially by species of the genera Chaetoceros on the French coast and Thalassiosira and Skeletonema on the English coast, (3) high microphytoplankton richness between April and August and (4) a less pronounced bloom near the French coast from late summer to early autumn dominated by the dinoflagellate Lepidodinium chlorophorum. During the study period, the abundance and diversity of the microphytoplankton in the phytoplankton assemblage were dominated by diatoms $(76.6 \%$ of the total number of cells and $64.3 \%$ of taxa diversity), in particular during the spring diatom bloom, as shown in other temperate ecosystems (Lemaire et al. 2002, Gameiro et al. 2007, Jouenne et al. 2007, Klein 2010). Diatoms are known to dominate the phytoplankton assemblage during periods of high nutrient concentrations and turbulence, whereas dinoflagellates are likely to dominate the phytoplankton population during periods of low turbulence and low nutrient concentrations (Mar- galef 1978). In our study, diatoms decreased in late spring along with the seasonal nutrient depletion, followed by an increase in dinoflagellates, in accordance with the reports in the literature.

Synechococcus and picoeukaryotes reached their maximum abundance in late spring/early summer on the English coast, whereas cryptophytes peaked during the spring diatom bloom on the French coast. According to Bell \& Kalff (2001), larger plankton cells (i.e. diatoms, dinoflagellates and cryptophytes in our study) are characteristic of nutrient-rich environments, whereas smaller forms (i.e. Synechococcus and picoeukaryotes in our study) predominate in nutrient-depleted environments. That is in accordance with our results concerning the seasonality of nutrient concentrations along the transect, and with the 4 hydrological areas described by Napoléon et al. (2012).

Double principal coordinate analysis (DPCoA) not only allowed us to distinguish intra-site and inter-site microphytoplankton diversity, but also to monitor the spatiotemporal variability in microphytoplankton diversity and to distinguish common patterns between seasons. DPCoA was also very useful to identify stations which were dominated by a single species. For example, we identified 2 species that dominated the phytoplankton assemblage: Phaeocystis globosa in May at Stn 4, and Lepidodinium chlorophorum in September at Stn 2, both species being responsible for harmful algal blooms (HAB).

An annual spring bloom of $P$. globosa is generally observed in the North Sea and the English Channel following the spring diatom bloom (Reid et al. 1990, Lancelot 1995, Cadee 1996, Jouenne et al. 2007, Pannard et al. 2008). In our study, P. globosa was observed only in May (on 5 May 2010), at Stn 4, at a concentration representing $95 \%$ of the total number of microphytoplankton cells. On 12 May 2010, P. globosa reached a concentration of 4700000 cells $\mathrm{I}^{-1}$ in the Bay of Somme (eastern English Channel, France) (REPHY, Ifremer network). Moreover, during the $10 \mathrm{~d}$ preceding the proliferation, unusual wind from the northeast was recorded (Météo France). We thus presume that the high P. globosa concentration observed at Stn 4 was a residual phenomenon of an event that took place in the eastern English Channel including the Bay of Somme. The same phenomenon was observed in 2012 by REPHY (Ifremer) with a high concentration of $P$. globosa $\left(440000\right.$ cells $\left.\mathrm{l}^{-1}\right)$ recorded in the same area (Cabourg, France) and during the same month associated with wind from the northeast the week preceding the proliferation. 
L. chlorophorum is known to be responsible for green-water events in the North Sea (Elbrachter \& Schnepf 1996), the English Channel, and the Bay of Biscay (Sournia et al. 1992, Gailhard 2003). During the year of study, this dinoflagellate was observed in September at Stn 2. The species is not toxic, but when the biomass is high it can generate large aggregates due to its high transparent exopolymer particle (TEP) production capacity (Claquin et al. 2008), which can cause local anoxia (Sournia et al. 1992), and may result in a high mortality rate in sedentary fauna. However, the concentrations recorded in the present study remained low and thus presumably did not present the risk of anoxia.

\section{Phytoplankton assemblage structure, primary production and productivity}

The present study not only advanced our understanding of the variability in the phytoplankton assemblage as a function of hydrological areas, level of anthropogenic influence or seasonality, but also enabled us to study the relationship between $\mathrm{P}^{\mathrm{B}}$ max and the phytoplankton assemblage structure and its consequences for $\mathrm{PP}_{\max }$.

As also reported by Irigoien et al. (2004), we recorded low microphytoplankton Shannon-Wiener $\left(H^{\prime}\right)$ and evenness $\left(J^{\prime}\right)$ indices during the spring diatom bloom. The high $H^{\prime}$ and $J^{\prime}$ of the microphytoplankton from summer to winter were measured during a period with low nutrient concentrations. During this period, small phytoplankton cells were dominant because they are able to uptake nutrients in nutrientdepleted environments due to their high surface:volume ratio (Raven 1998). Thus, we propose the codominance of small phytoplankton cells from summer to winter, and particularly the development of picoeukaryotes and Synechoccocus between the English coast and the centre of the English Channel in summer. In contrast, the spring diatom bloom (occurring from the centre of the Channel of the French Coast) was largely dominated by a single phytoplankton species, Chaetoceros socialis, which represented $86 \%$ of the total number of microphytoplankton cells. This result, i.e. the dominance of one species, is in agreement with results of studies by Reid et al. (1990), Irigoien et al. (2004) and Duarte et al. (2006).

A significant negative parabolic relationship was obtained between the microphytoplankton $J^{\prime}$ and $\mathrm{PP}_{\max }$ and between the microphytoplankton $H^{\prime}$ and $\mathrm{PP}_{\text {max }}$. Duarte et al. (2006) also showed a high negative parabolic link between $H^{\prime}$ and $\mathrm{PP}_{\max }$ and sug- gested that low $\mathrm{PP}_{\max }$ rates could reduce recovery from mortality and therefore reduce species diversity. Conversely, higher $\mathrm{PP}_{\max }$ could also reduce diversity through exclusion by competition because of the decrease in available resources. However, we found a positive parabolic relationship between microphytoplankton $S$ and $\mathrm{PP}_{\max }$, suggesting that high $\mathrm{PP}_{\max }$ levels were characterised by high species richness but that the community was dominated by only few taxa.

Only a few studies have focused on the relationship between species richness and productivity in marine ecosystems (Jouenne et al. 2007, Prowe et al. 2012). Productivity is found to be sometimes positively correlated with species richness, sometimes negatively, and sometimes not correlated at all (Waide et al. 1999, Mittelbach et al. 2001, Jouenne et al. 2007, Hillebrand $\&$ Matthiessen 2009). In the present study, we found no correlation between $\mathrm{P}^{\mathrm{B}}{ }_{\text {max }}$ and $J^{\prime}(\mathrm{R}=0.075, \mathrm{p}=$ $0.457), S(\mathrm{R}=0.032, \mathrm{p}=0.750)$ or $H^{\prime}(\mathrm{R}=0.086, \mathrm{p}=$ 0.396). As proposed by Prowe et al. (2012), physical and chemical parameters would be expected to drive the relationship between productivity and richness, the evenness index, or the Shannon-Wiener index. But we found no correlation in the 3 hydrological areas defined by the PTA, revealing that the degree of anthropogenic influence and consequently water mass properties do not influence the relationship between $\mathrm{P}^{\mathrm{B}}{ }_{\text {max }}$ and microphytoplankton diversity. Here we should mention a limitation of our study. The diversity of the pico- and nanophytoplankton cell fraction was not included in the calculation of the diversity levels due to the method used to characterise this fraction (flow cytometry). A better way to determine the diversity of the pico- and nanophytoplankton diversity is by molecular methods, even if this technique also has some limits. In the present study, we assumed that the majority of $\mathrm{PP}_{\max }$ is due to microphytoplankton cells and that we could therefore explore the relationship between microphytoplankton and diversity indexes. However, even knowing this limit, high levels of $\mathrm{P}^{\mathrm{B}}$ max were recorded during the development of small cells from late spring to the following winter, particularly during the proliferation of picoeukaryotes and Synechoccocus. Such a negative relationship between cell volume and productivity has already been reported (Malone \& Neale 1981). Conversely, Jouenne et al. (2007) found a positive relationship in their study in a French estuarine bay in the English Channel (Veys Bay). The inverse relationship between cell size and productivity is generally attributed to nutrient limitation. Indeed, the minimum limiting concentration decreases with a decrease in 
cell size (Montecino \& Quiroz 2000), which is in agreement with the proliferations of picoeukaryotes and Synechoccocus we observed in this study.

During the same study as the present one, Napoléon et al. (2012) showed that photosynthetic parameters were controlled by light during the spring diatom bloom on the French coast and that photoacclimation to low light occurred. We can assume that there was a higher chl a concentration per carbon biomass during the massive diatom bloom compared to the chl a concentration of small cells present in late spring and early summer, due to photoacclimation to high light. This allows us to account for the higher $\mathrm{P}^{\mathrm{B}}$ max (expressed as a function of the concentration of chl a) measured during the proliferation of picoeukaryotes and Synechoccocus, which was associated with low chl a concentrations. Thus, a significant negative relationship was found between $\mathrm{P}^{\mathrm{B}}$ max and the chl a concentration $(\mathrm{R}=-0.494, \mathrm{p}<0.0001)$. Diatoms and picoplankton belong to 2 functional groups; diatoms are characterized by a high concentration of chl a associated with low productivity, while the picoplankton is represented by small cells which are highly competitive for nutrient uptake and are highly productive.

\section{CONCLUSIONS}

We have shown that the spatial variability in the microphytoplankton assemblage is linked to the hydrological areas described in Napoléon et al. (2012) and that the temporal variability is controlled by seasonality.

We found a negative parabolic relationship between the microphytoplankton $J^{\prime}$ and $\mathrm{PP}_{\max }$ and between the microphytoplankton $H^{\prime}$ and $\mathrm{PP}_{\max }$. However, we found a positive parabolic relationship between microphytoplankton $S$ and $\mathrm{PP}_{\max }$ suggesting that high $\mathrm{PP}_{\max }$ was characterised by high microphytoplankton species richness but that the community was dominated by only a few species.

We highlighted the high $\mathrm{P}^{\mathrm{B}}{ }_{\text {max }}$ of picoplankton, yet picoplankton are frequently not taken into account in temperate coastal ecosystems (Jouenne et al. 2007, Pannard et al. 2008, Klein 2010, Klein et al. 2011). Results of the present study underline the importance of taking into account the dominant functional group rather than the degree of diversity to explain the level of $\mathrm{P}_{\text {max }}^{\mathrm{B}}$. Our analysis focused on variability at the seasonal scale. It would also be interesting to explore the relationships between $\mathrm{P}^{\mathrm{B}}{ }_{\text {max }}$ and diversity at a higher sampling frequency.
Acknowledgements. This study was supported by the European project: Interreg 4a CHannel integrated Approach for Marine Resource Management 3 (CHARM3). We thank Bruno Fontaine, Bertrand Le Roy, Jean-Paul Lehodey, Laurent Perez, Olivier Pierre-Duplessix and Emilie Rabiller for their technical assistance. The authors are grateful to the CREC marine station for material assistance and to the officers and crew of the Normandie-Brittany Ferries for providing facilities for this study.

\section{LITERATURE CITED}

Abrams PA (1995) Monotonic or unimodal diversity-productivity gradients: What does competition theory predict? Ecology 76:2019-2027

Agawin NSR, Duarte CM, Agusti S (2000) Nutrient and temperature control of the contribution of picoplankton to phytoplankton biomass and production. Limnol Oceanogr 45:591-600

Aminot A, Chaussepied M (1983) Manuel des analyses chimiques en milieu marin. CNEXO, Brest

Aminot A, Kérouel R (2007) Dosage automatique des nutriments dans les eaux marines. Quae, Versailles

Anning T, MacIntyre HL, Pratt SM, Sammes PJ, Gibb S, Geider RJ (2000) Photoacclimation in the marine diatom skeletonema costatum. Limnol Oceanogr 45: 1807-1817

Behrenfeld MJ, Falkowski PG (1997) A consumer's guide to phytoplankton primary productivity models. Limnol Oceanogr 42:1479-1491

> Behrenfeld MJ, Prasil O, Babin M, Bruyant F (2004) In search of a physiological basis for covariations in lightlimited and light-saturated photosynthesis. J Phycol 40: $4-25$

Bell T, Kalff J (2001) The contribution of picophytoplankton in marine and freshwater systems of different trophic status and depth. Limnol Oceanogr 46:1243-1248

Cadee GC (1996) Accumulation and sedimentation of Phaeocystis globosa in the Dutch Wadden Sea. J Sea Res 36:321-327

> Chase JM (2010) Stochastic community assembly causes higher biodiversity in more productive environments. Science 328:1388-1391

Chessel D, Dufour AB, Thioulouse J (2004) The ade4 package - I: One-table methods. R news 4:5-10

- Claquin P, Probert I, Lefebvre S, Veron B (2008) Effects of temperature on photosynthetic parameters and TEP production in eight species of marine microalgae. Aquat Microb Ecol 51:1-11

> Claquin P, Longphuirt SN, Fouillaron P, Huonnic P, Ragueneau O, Klein C, Leynaert A (2010) Effects of simulated benthic fluxes on phytoplankton dynamic and photosynthetic parameters in a mesocosm experiment (Bay of Brest, France). Estuar Coast Shelf Sci 86:93-101

> Cugier P, Billen G, Guillaud JF, Garnier J, Menesguen A (2005) Modelling the eutrophication of the Seine Bight (France) under historical, present and future riverine nutrient loading. J Hydrol (Amst) 304:381-396

Davison IR (1991) Environmental effects on algal photosynthesis: temperature. J Phycol 27:2-8

Domingues RB, Barbosa A, Galvao H (2005) Nutrients, light and phytoplankton succession in a temperate estuary (the Guadiana, south-western Iberia). Estuar Coast Shelf Sci 64:249-260 
Dray S, Dufour AB (2007) The ade4 package: implementing the duality diagram for ecologists. J Stat Softw 22:1-20

> Duarte P, Macedo MF, da Fonseca LC (2006) The relationship between phytoplankton diversity and community function in a coastal lagoon. Hydrobiologia 555:3-18

Elbrachter M, Schnepf E (1996) Gymnodinium chlorophorum, a new, green, bloom-forming dinoflagellate (Gymnodiniales, Dinophyceae) with a vestigial prasinophyte endosymbiont. Phycologia 35:381-393

Estrada M, Varela RA, Salat J, Cruzado A, Arias E (1999) Spatio-temporal variability of the winter phytoplankton distribution across the Catalan and North Balearic fronts (NW Mediterranean). J Plankton Res 21:1-20

Falkowski PG, Raven JA (2007) Aquatic photosynthesis. Princeton University Press, Princeton, NJ

Gailhard I (2003) Analyse de la variabilité spatio-temporelle des populations microalgales côtières observées par le 'REseau de surveillance du PHYtoplancton et des phycotoxines' (REPHY). Thése de Doctorat, Université de la Méditerranée, Aix-Marseille II

Gailhard I, Durbec JP, Beliaeff B, Sabatier R (2003) Écologie $\mathrm{du}$ phytoplancton sur les côtes françaises: comparaison inter-sites. C R Biol 326:853-863

Gameiro C, Cartaxana P, Brotas V (2007) Environmental drivers of phytoplankton distribution and composition in Tagus Estuary, Portugal. Estuar Coast Shelf Sci 75:21-34

> Gamfeldt L, Hillebrand H (2011) Effects of total resources, resource ratios, and species richness on algal productivity and evenness at both metacommunity and local scales. PLoS ONE 6(7):e21972

> Hillebrand H, Matthiessen B (2009) Biodiversity in a complex world: consolidation and progress in functional biodiversity research. Ecol Lett 12:1405-1419

- Huisman J, Weissing FJ (1995) Competition for nutrients and light in a mixed water column: a theoretical analysis. Am Nat 146:536-564

Huston MA, Deangelis DL (1994) Competition and coexistence: the effects of resource transport and supply rates. Am Nat 144:954-977

Irigoien X, Huisman J, Harris RP (2004) Global biodiversity patterns of marine phytoplankton and zooplankton. Nature 429:863-867

> Jones KJ, Gowen RJ, Tett P (1984) Water column structure and summer phytoplankton distribution in the Sound of Jura, Scotland. J Exp Mar Biol Ecol 78:269-289

> Jouenne F, Lefebvre S, Veron B, Lagadeuc Y (2005) Biological and physicochemical factors controlling short-term variability in phytoplankton primary production and photosynthetic parameters in a macrotidal ecosystem (eastern English Channel). Estuar Coast Shelf Sci 65: 421-439

> Jouenne F, Lefebvre S, Veron B, Lagadeuc Y (2007) Phytoplankton community structure and primary production in small intertidal estuarine-bay ecosystem (eastern English Channel, France). Mar Biol 151:805-825

Klein C (2010) Etude des dynamiques du phytoplancton en manche orientale et occidentale. Approche écophysiologique. Thése soutenue sur un ensemble de travaux. Université de Caen Basse-Normandie

Klein C, Claquin P, Pannard A, Napoleon C, Le Roy B, Veron B (2011) Dynamics of soluble extracellular polymeric substances and transparent exopolymer particle pools in coastal ecosystems. Mar Ecol Prog Ser 427:13-27

> Lancelot C (1995) The mucilage phenomenon in the continental coastal waters of the North Sea. Sci Total Environ
165:83-102

> Lemaire E, Abril G, De Wit R, Etcheber H (2002) Distribution of phytoplankton pigments in nine European estuaries and implications for an estuarine typology. Biogeochemistry 59:5-23

Lippemeier S, Hartig P, Colijn F (1999) Direct impact of silicate on the photosynthetic performance of the diatom Thalassiosira weissflogii assessed by on- and off-line PAM fluorescence measurements. J Plankton Res 21: 269-283

Loreau M (1998) Biodiversity and ecosystem functioning: a mechanistic model. Proc Natl Acad Sci USA 95:5632-5636

> Malone TC, Neale PJ (1981) Parameters of light-dependent photosynthesis for phytoplankton size fractions in temperate estuarine and coastal environments. Mar Biol 61: 289-297

Margalef R (1978) Life-forms of phytoplankton as survival alternatives in an unstable environment. Oceanol Acta 1: 493-509

> Menesguen A, Hoch T (1997) Modelling the biogeochemical cycles of elements limiting primary production in the English Channel. I. Role of thermohaline stratification. Mar Ecol Prog Ser 146:173-188

Mittelbach GG, Steiner CF, Scheiner SM, Gross KL and others (2001) What is the observed relationship between species richness and productivity? Ecology 82:2381-2396

> Montecino V, Quiroz D (2000) Specific primary production and phytoplankton cell size structure in an upwelling area off the coast of Chile $\left(30^{\circ} \mathrm{S}\right)$. Aquat Sci 62:364-380

> Napoléon C, Claquin P (2012) Multi-parametric relationships between PAM measurements and carbon incorporation, an in situ approach. PLoS ONE 7:e40284

> Napoléon C, Raimbault V, Fiant L, Riou P, Lefebvre S, Lampert L, Claquin P (2012) Spatiotemporal dynamics of physicochemical and photosynthetic parameters in the central English Channel. J Sea Res 69:43-52

Pannard A, Claquin P, Klein C, Le Roy B, Veron B (2008) Short-term variability of the phytoplankton community in coastal ecosystem in response to physical and chemical conditions' changes. Estuar Coast Shelf Sci 80: 212-224

> Pavoine S, Dufour AB, Chessel D (2004) From dissimilarities among species to dissimilarities among communities: a double principal coordinate analysis. J Theor Biol 228: 523-537

> Pielou EC (1966) The measurement of diversity in different types of biological collections. J Theor Biol 13:131-144

> Prowe AEF, Pahlow M, Oschlies A (2012) Controls on the diversity-productivity relationship in a marine ecosystem model. Ecol Model 225:167-176

> Raven JA (1998) The twelfth Tansley lecture. Small is beautiful: the picophytoplankton. Funct Ecol 12:503-513

> Reid PC, Lancelot C, Gieskes WWC, Hagmeier E, Weichart G (1990) Phytoplankton of the North Sea and its dynamics: a review. Neth J Sea Res 26:295-331

Sournia A, Belin C, Billard C, Catherine M and others (1992) The repetitive and expanding occurence of a green, bloom-forming dinoflagellate (Dinophyceae) on the coasts of France. Cryptogam Algol 13:1-13

Ter Braak CJF (1986) Canonical correspondence analysis: a new eigenvector technique for multivariate direct gradient analysis. Ecology 67:1167-1179

Ter Braak CJF, S̆milauer P (2002) CANOCO reference manual and CanoDraw for Windows user's guide: Software for canonical community ordination (version 4.5). Micro- 
computer Power, Ithaca, NY. www.canoco.com

Tilman D, Lehman CL, Thomson KT (1997) Plant diversity and ecosystem productivity: theoretical considerations. Proc Natl Acad Sci USA 94:1857-1861

Utermöhl (1931) Neue Wege in der quantitativen Erfassung des Planktons. (Mit besonderer Berücksichtigung des Ultraplanktons). Verh Int Verein Theor Angew Limnol 5: 567-595

Vaulot D, Courties C, Partensky F (1989) A simple method to preserve oceanic phytoplankton for flow cytometric analyses. Cytometry 10:629-635
Videau C, Ryckaert M, L'Helguen S (1998) Phytoplankton in the Bay of Seine (France). Influence of the river plume on primary productivity. Oceanol Acta 21:907-921

> Waide RB, Willig MR, Steiner CF, Mittelbach G and others (1999) The relationship between productivity and species richness. Annu Rev Ecol Syst 30:257-300

Ward JH (1963) Hierarchical grouping to optimize an objective function. J Am Stat Assoc 58:236-244

Welschmeyer NA (1994) Fluorometric analysis of chlorophyll $a$ in the presence of chlorophyll $b$ and pheopigments. Limnol Oceanogr 39:1985-1992 
Appendix. List of phytoplankton taxa and the codes used in Fig. 4C

\begin{tabular}{|c|c|c|c|}
\hline Taxon & Code & Taxon & Code \\
\hline Bacillariophyceae & & Skeletonema spp. & $\mathrm{Sk}$ \\
\hline Actinocyclus spp. & $\mathrm{Ac}$ & Stellarima spp. & $\mathrm{St}$ \\
\hline Asterionellopsis glacialis & A_g & Synedra spp. & Sy \\
\hline Asterolampra spp. & Ast & Thalassionema nitzschioides & T_n \\
\hline Bacillaria paxillifer & Ba_p & Thalassiosira spp. & Th \\
\hline Biddulphia spp. & $\overrightarrow{\mathrm{Bi}}$ & T. antarctica & T_a \\
\hline Brockmanniella brockmannii & B_b & T. levanderi & T_l \\
\hline Cerataulina pelagica & C_p & T. minima & T_m \\
\hline Chaetoceros spp. & $\mathrm{Ch}$ & T. nordenskioeldii & T_no \\
\hline C. danicus & C_da & T. rotula & T_r \\
\hline C. debilis & C_de & Toxarium spp. & To \\
\hline C. didymus & C_di & Triceratium spp. & Tri \\
\hline C. fragilis & $\mathrm{C}_{-} \mathrm{f}$ & Other Bacillariophyceae & Bae \\
\hline C. socialis & C_s & Dinophyceae & \\
\hline Corethron criophilum & C_cr & Akashiwo sanguinea & A_S \\
\hline Coscinodiscus spp. & $\overline{\operatorname{Cos}}$ & Alexandrium spp. & $\overline{\mathrm{Al}}$ \\
\hline Cyclotella sp. & Cy & Ceratium spp. & Cer \\
\hline Cylindrotheca closterium & C_C & Dinophysis spp. & Di \\
\hline Dactyliosolen fragilissimus & D_f & Diplopelta spp. & Die \\
\hline Delphineis surirella & D_s & Diplopsalis spp. & Dio \\
\hline Detonula sp. & $\overline{\mathrm{De}}$ & Dissodinium spp. & Dis \\
\hline Detonula spp. & Det & Gonyaulax spp. & Go \\
\hline Ditylum brightwellii & D_b & Gymnodinium spp. & Gym \\
\hline Eucampia zodiacus & E_z & Gyrodinium spp. & Gyr \\
\hline Fallacia sp. & $\overline{\mathrm{Fa}}$ & G. spirale & G_sp \\
\hline Fragilaria spp. & $\mathrm{Fr}$ & Heterocapsa niei & H_n \\
\hline Grammatophora spp. & Gr & H. triquetra & H_tr \\
\hline Guinardia spp. & $\mathrm{Gu}$ & Katodinium spp. & $\mathrm{Ka}$ \\
\hline G. delicatula & G_d & Lepidodinium chlorophorum & L_C \\
\hline G. striata & G_s & Peridinium spp. & $\mathrm{Pe}$ \\
\hline Gyrosigma spp. & Gy & Polykrikos spp. & Pol \\
\hline Hantzschia sp. & Han & Prorocentrum spp. & $\operatorname{Pr}$ \\
\hline Haslea sp. & Has & P. gracile & P_gr \\
\hline Helicotheca tamesis & H_t & P. micans & P_m \\
\hline Lauderia annulata & La_a & P. minimum & P_mi \\
\hline Leptocylindrus spp. & $\mathrm{Le}$ & Protoperidinium spp. & Pro \\
\hline L. curvatulus & L_cu & P. bipes & $\mathrm{P} \_\mathrm{b}$ \\
\hline L. danicus & L_d & Pyrocystis spp. & Py \\
\hline L. minimus & L_m & Scrippsiella spp. & Scr \\
\hline Licmophora spp. & $\mathrm{Li}$ & Torodinium spp. & Tor \\
\hline Lithodesmium undulatum & L_u & Gymnodiniaceae & Gae \\
\hline Melosira spp. & $\mathrm{Me}$ & Other Dinophyceae & Dae \\
\hline Meuniera membranacea & M_m & Chlorophyceae & \\
\hline Navicula spp. & $\overline{\mathrm{Na}}$ & Scenedesmus spp. & Sce \\
\hline Nitzschia spp. & $\mathrm{Ni}$ & Other Chlorophyceae & Cae \\
\hline N. longissima & N_l & Chrysophyceae & Chae \\
\hline Odontella spp. & Od & Coccolithophyceae & Coae \\
\hline O. aurita & O_a & Cryptophyceae & Crae \\
\hline O. sinensis & O_s & Dictyochophyceae & \\
\hline Paralia sulcata & P_S & Dictyocha spp. & Dic \\
\hline Plagiogramma spp. & $\mathrm{Pl}$ & Euglenophyceae & $\mathrm{Eu}$ \\
\hline Pleurosigma spp. & Ple & Prasinophyceae & \\
\hline Podosira spp. & Po & Pyramimonas spp. & Pyr \\
\hline Pseudo-nitzschia spp. & Pn & Other Prasinophyceae & Pra \\
\hline Rhaphoneis spp. & $\mathrm{Rh}$ & Prymnesiophyceae & \\
\hline Rhizosolenia imbricata & R_i & Phaeocystis globosa & P_g \\
\hline R. pungens & R_p & Chlorodendrophyceae & \\
\hline$R$. setigera & R_S & Tetraselmis spp. & $\mathrm{Te}$ \\
\hline R. stoltherforthii & R_so & Raphidophyceae & \\
\hline R. styliformis & R_sy & Heterosigma akashiwo & H_a \\
\hline
\end{tabular}

